partykularyzmu kultu żydowskiego i jego korekty w powszechną religię chrześcijańską (ss. 105-263). Autorka nie jest jednak konsekwentna w stosowaniu tego kryterium i używa go dosyć arbitralnie. Nie zawsze bowiem tam, gdzie pojawia się na scenie Tryfon, widzi ona początek nowej sekcji (por. np. Dial 10,$2 ; 19,1 ; 27,1 ; 28,1 ; 32,1 ; 35,1 ; 36,1 ; 38,1 ; 39,7$ itd.). Odnosi się wrażenie, że podział został dokonany w taki sposób, aby uzasadnić Grundthese pracy. Otóż, z punktu widzenia metodologicznego powinno być raczej odwrotnie, z właściwie dokonanego podziału powinien ukazać się temat centralny Dialogu. A jest nim, jak wszystko wskazuje, chrystologia. Justyn stara się uzasadnić, że Jezus jest jednocześnie Mesjaszem żydowskim i kimś zdecydowanie więcej: właśnie Mesjaszem uniwersalnym, Synem Bożym preegzystującym u Ojca i objawiającym się Izraelowi w teofaniach pod postacią posłańca (angelos), Grekom jako Logos spermatikos, a ostatecznie wszystkim w postaci ludzkiej. Tylko przyjęcie takiego Mesjasza czyni z chrześcijaństwa nową religię i jakościowo zmienia cześć oddawaną Bogu. Argumentacja Justyna o tymczasowości Prawa Mojżeszowego prowadzi do chrystologii, a prezentacja chrześcijaństwa jako nowej i powszechnej religii, jest z chrystologii wyprowadzona i na niej się opiera. To prawda, że trzeci element pojawia się na końcu pisma, ale z tego wcale nie wynika, że jest tematem docelowym. Chrystologia nie jest przedstawiona w Dialogu w funkcji argumentacji za chrześcijaństwem jako nową religią, lecz odwrotnie. Autorka wyraźnie analizuje Dialog z perspektywy bardziej historycznej i religioznawczej niż teologicznej w sensie ścisłym. A taka perspektywa może być często myląca. Mimo tych zastrzeżeń praca jest w wielu punktach dobrą syntezą badań nad Dialogiem, a piękne wydanie z uwspółcześnioną bibliografią w j. niemieckim, dokładnymi indeksami cytatów biblijnych, imion, autorów antycznych czy nawet terminów greckich czyni z niej użyteczne narzędzie do studiów nad pismem Justyna.

Ks. Leszek Misiarczyk - Płock

\title{
Peter SCHÄFER, Judeophobia. Attitudes toward the Jews in the Ancient World, Cambridge - London 1997, Harvard University Press, s. XII+306.
}

Lata dziewięćdziesiąte naszego wieku przyniosły ze sobą wzrost i tak już znacznego zainteresowania dziejami żydowskiej diaspory. Wystarczy tu wymienić choćby takie prace jak: S. Cohen, Diaspora in Antiquity, Atlanta 1993; J. G. M. Barclay, Jews in the Mediterranean Diaspora, Edinburgh 1996; L. H. Feldman, Jew and Gentile in the Ancient World, Princeton 1996. Nowe publikacje prezentują niekiedy poszerzone spektrum badawcze, dzięki między innymi wykorzystaniu pojęć z zakresu socjologii (zob. W. Bergmann Ch. Hoffmann, ,Kalkül oder Massenwahn?” Eine soziologische Interpretation 
der antijüdischen Unruhen in Alexandria $38 n$. Chr., w: Antisemitismus und jüdische Geschichte. Studien zu Ehren von Herbert A. Straus, ed. R. Erb - M. Schmidt, Berlin 1987, s. 15-46; O. Bucci, La genesi ellenistica dell'antigiudaismo romano. Alle origini dell' antisemitismo cristiano, „Lateranum” 52:1986, 51-82; S. Wilson, Anti-Judaism in early Christianity. Separation and polemic, Waterloo 1986; M. S. Taylor, Anti-Judaism and early Christian Identity. A Critique of the scholary Identity, Leiden - New York - Köln 1995) W konsekwencji umożliwia to kształtowanie nowych podejść metodologicznych do „starych” zagadnień.

Peter Schäfer, profesor na Freie Universität Berlin, zajmujący się od wielu lat dziejami Żydów w Palestynie, a ostatnio także diasporą, pokusił się o nakreślenie panoramy stosunków świata antycznego (z wyłączeniem chrześcijaństwa) do Żydów. Nie chodzi jednak tutaj o całość wzajemnych relacji i odniesień, lecz, jak sam autor zaznacza, interesują go „głównie ... wrogie stosunki wobec Żydów". Autor nie zamierza zajmować się wszystkimi aspektami i odcieniami relacji pomiędzy Żydami, ale ich politeistycznymi sąsiadami (s. 7). To zamierzenie ma zostać wykonane poprzez wykorzystanie jedynie tych źródeł, które są proweniencji „pogańskiej”. Będzie to więc spojrzenie „na stare zagadnienie w nowym ujęciu (approach), które uwzględnia wszystkie te źródła, które dotyczą dziejów wrogości wobec Żydów w świecie grecko-rzymskim, tzw. pogańskiego lub starożytnego antysemityzmu" (s. 6). Dzięki temu zabiegowi udało się autorowi stworzyć oryginalną (na tle istniejącej literatury) koncepcję dotyczącą istoty antysemityzmu w świecie ,pogańskim”.

Książka została podzielona na trzy części: I. Kim są Żydzi?, II. Dwa klucze wydarzeń historycznych, III. Centra konfliktów. W usystematyzowaniu treści pomagają również zawarte w nich rozdziały. We wprowadzeniu do książki (s. 1-11) zostały omówione dwa dominujące modele metodologiczne, które stosowano w historiografii dla wyjaśnienia przyczyn wrogości wobec Żydów. Szkoła „substancjonalistyczna” (lub „esencjonalistyczna”) jest zdania, że wyjątkowe religijne, kulturalne i społeczne (social) elementy judaizmu były same w sobie powodem tego, co później określano między innymi mianem , antysemityzmu" (s. 2 nn.). Druga szkoła metodologiczna zakłada, że powodem konfliktów między Żydami a „poganami” nie była swoista „esencja” judaizmu, ale raczej konkretne polityczne konflikty, zogniskowane w trzech ośrodkach, jakimi były (stosując kolejność przyjętą przez I. Heinemanna: Antisemitismus, RE Suppl. V 3-43) Syro-Palestyna, Egipt i Rzym (s. 4 nn.). Schäfer nie opowiada się bezpośrednio ani za jednym ani za drugim modelem eksplanacyjnym, ponieważ dużo korzystniejsze $\mathrm{z}$ historycznego punktu widzenia jest, jego zdaniem, połączenie obu przedstawionych podejść metodologicznych, jak to czyni większość badaczy (s. 7 n.).

Celem I części (s. 13-118) jest analiza dostępnego materiału źródłowego, który odnosi się do żydowskiej tradycji (Wygnanie z Egiptu), religii i obyczajów 
(Żydowski Bóg, Powstrzymywanie się od wieprzowiny, Szabat, Obrzezanie, Prozelityzm). Teksty źródłowe zostały omówione pod kątem ich pochodzenia, autentyczności (jeśli trzeba), funkcjonowania powtarzających się motywów antyżydowskich (np. misoxenia/mizantropia), a przede wszystkim stosunku do Żydów w kategoriach: pozytywny/negatywny. Jak się okazuje istnieje względnie duże zróżnicowanie, jeśli chodzi o postawy starożytnych do instytucji i tradycji żydowskich, chociaż z przewagą wrogiego nastawienia.

Część II (s. 119-160) zajmuje się m.in. problemami kolonii żydowskich osadników wojskowych na Elefantynie pod koniec V w. p.n.e. Aramejskie papirusy pozwalają prześledzić okoliczności związane z pierwszym znanym nam wystąpieniem antyżydowskim (410 r. p.n.e.). Godna uwagi jest teza, że mieszkający tam Żydzi byli świadomi nie tylko wrogości kapłanów Chnuma, którą ci wobec nich żywili, ale także konieczności mniej lub bardziej wymuszonej rezygnacji z całopalnych ofiar $\mathrm{z}$ jagniąt, bo te w znacznej mierze przyczyniały się do ich kłopotów (s. 132 n.).

Kolejnym przypadkiem rozważanym w tej części książki (s. 136-160) był pogrom w Aleksandrii w 38 roku. Podstawę do rekonstrukcji tamtejszych wydarzeń, które miały swój epilog za panowania cesarza Klaudiusza, są relacje zhellenizowanego Żyda Filona w Przeciw Flakkusowi oraz Poselstwo do Gajusza, dwa edykty cesarza Klaudiusza zamieszczone w Dawnych dziejach Izraela (XIX 280-291) Józefa Flawiusza, papirus zwany Papirusem Londyńskim 73-100, (wyd. H. I. Bell, The Jews and Christians in Alexandria, London 1924, s. 25), a także Akta Izydora i Lampona (wyd. H. A. Musurillo, The Acts of the Pagan Martyrs. Acta Alexandrinorum, Oxford 1954, s.18-26). Zwraca tutaj szczególnie uwagę rzetelna analiza trzech aktów legislacyjnych związanych z osobą cesarza Klaudiusza. Trudno jest tutaj doprawdy zdobyć się na jakąś odkrywczą tezę wobec istniejącej już ogromnej literatury. Może jednak budzić uzasadnione zdziwienie przypisywanie zhellenizowanym Egipcjanom zamiaru rywalizacji o obywatelstwo Aleksandrii z tamtejszymi Żydami (s. 160). Wynika to zapewne z tego, iż autor dosyć literalnie odbiera te partie tekstu w Przeciw Flakkusowi, które mówią o udziale Egipcjan w prześladowaniu wyznawców Jahwe. Wydaje się jednak, że nie w pełni został tutaj wykorzystany artykuł K. Goudiaana, (Ethnical Strategies in Greco-Roman Egypt, w: Ethnicity in Hellenistic Egypt, ed. P. Bilde et al., Aahrus 1992, s. 88 nn.). Badacz ów zwrócił uwagę, że słowo „Egipcjanin” było używane zarówno przez Żydów jak i aleksandyjskich Greków dla wzajemnego oczerniania się. U podstaw tego twierdzenia leży fakt, że zarówno Józef Flawiusz i Filon dosyć swobodnie i zamiennie stosują go, gdy opisują zachowanie się wrogów ich ludu: raz są oni Grekami, raz Egipcjanami.

Pragnienie przypisania Egipcjanom roli wiodącej w tych wystąpieniach przeciwko Żydom, wiąże się bliżej z często pojawiającą się na kartach książki tezą, że Egipt przedhellenistyczny był źródłem niechęci do nich (s. 135, 145, 
169). Właśnie III część pracy (s. 161-211), będąca niejako ukłonem w stronę funkcjonalistów, zajmuje się rolą i wkładem trzech wymienionych już „Konfliktionsherde" w ukształtowanie się wyobrażeń antysemickich. Jednak autor, inaczej niż Heinemann, daje pierwszeństwo ośrodkowi egipskiemu, zamiast syro-palestyńskiemu w tworzeniu i propagowaniu zniekształconego obrazu Żydów i tego, co jest z nimi związane. Jest to słuszne „przesunięcie”, bowiem to kraj Apiona, w dużej mierze dzięki Przeciw Apionowi Józefa Flawiusza, a nie obszar starcia Antiocha IV Epifanesa z żydowskim nacjonalizmem religijnym (Syro-Palestyna), posiada prymat w kreowaniu pomówień wobec wyznawców Jahwe. To stamtąd przecież pochodzila zniekształcona opowieść o wygnaniu Żydów, rozpowszechniana przez Manetona (jak chce autor), Lizymacha, Apiona i Charemona, którzy notabene byli Greko-Egipcjanami. Egipskiego rodowodu jest też, zdaniem Schäfera, często powtarzane w różnych formach posądzenie o wrogość wobec obcych (misoxenial mizantropia) oraz o bezbożność. Propagowali je wymieniani już pisarze greko-egipscy. Miały one zostać następnie zaszczepione Grekom, w czym szczególnie ważną rolę miał odegrać Manethon. Ci zaś, ze swej strony zajęli się ich rozpowszechnianiem, nadając im przy tym swój własny kontekst: Żydzi, jako naród nienawidzą wszystkich ludzi z wyjątkiem siebie (s. 175). Po raz pierwszy, w takiej czy innej formie, znalazło to swój wyraz u Hekatajosa z Abdery (w: Diodor Sycylijski, Biblioteka 40, 3, 4), który czerpał swe wiadomości o kraju faraonów od egipskich kapłanów. Wyjątkowy posmak zyskał ten zarzut w chwili, gdy został on poszerzony o przysięgę nienawiści wobec Greków, rokrocznie odnawianą przy okazji składania ofiary z jednego przedstawiciela tej nacji (zob. Józef Flawiusz, Przeciw Apionowi II 91-96).

Wiele ambiwalencji można natomiast dostrzec w postrzeganiu Żydów przez rzymskich literatów, takich jak Cyceron, Juwenalis, czy Tacyt. Autor dostrzega, że stosunek Rzymian do nich jest dużo bardziej złożony, niż ten, jaki przejawiali Grecy i Egipcjanie. Rzymianie niewątpliwie odziedziczyli i zaabsorbowali do pewnego stopnia ,nieokrzesaną (blunt) egipską nienawiść i grecką pogardę dla wyrzutków ludzkiej społeczności (the outcasts of humankind)”. Co więcej „odczuwali oni pociąg, na który reagowali albo z sympatią (Warron, prozelici, Julian Apostata) i rzeczywiście nawróceniem albo ze strachem, niechęcią i nienawiścią" (s. 194 n.; por. s. 192, 210). Dopiero od tego momentu można mówić o judeofobii. Trzeba przyznać, że jest to dosyć oryginalna koncepcja i poniekąd wyjaśnia, dlaczego nie są nam znane żadne „popularne" wystąpienia przeciw Żydom w zachodniej części cesarstwa rzymskiego, tak jak to miało miejsce na Wschodzie ${ }^{1}$. Warto także zauważyć, iż Egipcjan,

${ }^{1}$ Nie bez znaczenia była różnica w populacji Żydów, których znacznie więcej zamieszkiwało na Wschodzie. 
Greków i Rzymian łączy, przybierające różne formy, poczucie zagrożenia, jakie odczuwano w związku z obecnością czcicieli Jahwe (s. 203).

Niemniej istotną rolę niż pozostałe odgrywa ostatni rozdział, zatytułowany: Antysemityzm (s. 197-211). Jest on próbą odpowiedzi na złożony kompleks pytań, związanych z zastosowaniem tego pojęcia w odniesieniu do antyku. Wydaje się, że najistotniejsze to: 1) czy istniał zawsze ten sam rodzaj wrogości i nienawiści do Żydów w historii? 2) czy jest coś wyjątkowego w tych uczuciach, co mogłoby wyróżniać Żydów spośród innych grup etnicznych lub religijnych? Odpowiedź na te zagadnienia jest oparta na krytyce tezy G. I. Langmuira (Toward a Definition of Antisemitism, Berkeley - Los Angeles - Oxford 1990, s. 328-334), zgodnie z którą można dostrzec w dziejach trzy rodzaje wrogości wobec Żydów, z których każdy jest oparty na odmiennych podstawach:

1. Rzeczywista wrogość (realistic hostility), tzn. mająca oparcie w obserwacjach otaczającej rzeczywistości,

2. Ksenofobia występująca wtedy, gdy opinie o danej grupie oparte są na tym, co w przeszłości zrobiły poszczególne, przynależne do niej jednostki. Najistotniejsze w tej kategorii wrogości jest to, że zawiera ona ,ziarno prawdy" (kernel of truth), np. skoro w przeszłości członkowie Sanhedrynu skazali Chrystusa na śmierć, to znaczy, że wszyscy Żydzi są Jego zabójcami.

3. Chimeria odnosząca się do tych twierdzeń o członkach danej grupy, które nigdy nie zostały empirycznie zaobserwowane. Neologizm ów pochodzi od greckiego słowa chimaira i oznacza baśniowego potwora o ognistym oddechu. Stąd w przeciwieństwie do twierdzeń ksenofobicznych, chimeryczne prezentują fantazje, wymysły wyobraźni i potworności, które nie zawierają „ziarna prawdy".

Krytykując, a jednocześnie wykorzystując ten model wrogich zachowań, Schäfer inaczej niż Langmuir jest zdania, że antysemityzm, równoznaczny z chimerią, istniał już w starożytności (pomówienia o zabójstwo Greka i nienawiść do innych nacji). W późniejszym czasie zostały one przekształcone w oskarżenie o rytualne zabijanie dzieci, do czego później chrześcijanie dodali zatruwanie studni i konszachty z diabłem. Można więc dojść do wniosku, że jeśli nie ten sam, to przynajmniej podobny rodzaj wrogości wobec innych przypisywano Żydom, a co za tym idzie chrześcijanie posiadali podobne złowrogie wyobrażenia o nich samych w starożytności, średniowieczu i w czasach późniejszych.

Co do drugiego z zagadnień (czy wobec Żydów odczuwano jedyny w swym rodzaju typ wrogości), to odwołując się do faktu zaistnienia Holokaustu Schäfer twierdzi, że wrogość wobec Żydów miała rzeczywiście wyjątkowy stopień natężenia i charakter. Za swoistą prereminiscencję owej „wyjątkowości” można zapewne uznać radę, jaka została udzielona Antiochowi IV przez jego kanclerzy. Kierując się nią władca miał wziąć szturmem Jerozolimę i zupełnie 
wyniszczyć naród żydowski, bowiem on jeden spośród wszystkich innych unika relacji z jakimikolwiek innymi ludźmi i spogląda na nich wszystkich jako na swoich wrogów (Diodor Sycylijski, Biblioteka, 34-35 1, 1; 5). Wiele podobieństwa można też dostrzec w słowach dostojnika Hamana, skierowanych do perskiego króla Ahasuerusa, w których za podstawę do całkowitego rozprawienia się z Żydami stanowi ich wroga, aspołeczna postawa, oraz odmienna religia i prawa (Józef Flawiusz, Starożytne dzieje Izraela XI, 212 n.).

Określenie posądzeń o mizantropię/ ksenofobię jako „rdzenia (the core) antysemityzmu" (s. 209 n.) rozwiązuje więc problem, z jakim w XX wieku borykało się wielu historyków: czy, a jeśli tak to kiedy, można mówić o istnieniu antysemityzmu w świecie greckorzymskim. Pojawia się jednak fundamentalne $\mathrm{z}$ historycznego punktu widzenia pytanie: dlaczego istniały takie posądzenia? Jako że ludzkie zachowanie wynika z konkretnych przyczyn, to tym samym i dla oskarżeń o mizantropię/ ksenofobię należy znaleźć źródło. Niemal odruchowo zwykło utożsamiać się je z żydowskim separatyzmem, który obiektywnie rzecz biorąc istniał. Jednak autor zastrzega, że skoncentrowanie się na ujęciu substancjonalistycznym, opartym na idei monolitycznego antysemityzmu, który wynika z samej istoty judaizmu, wywołuje „,na pewno dużo niebezpieczniejsze ryzyko pomieszania przyczyny z pretekstem (the risk of confusing cause with pretext)” i w konsekwencji czyni Żydów winnymi „tego, co im się przydarzyło". Ten zaś, kto stosuje tylko model funkcjonalistyczny, naraża się na ryzyko „rozmycia” fenomenu, który opisuje, tj. antysemityzmu, na ciągle zmieniające się polityczne i społeczne (social) relacje, które niewiele wyjaśniają (s. 209). Jedynym wyjściem z tej patowej sytuacji jest, według autora, połączenie obu podejść metodologicznych. Tak więc, aby „stworzyć” antysemityzm, potrzebny jest antysemita oraz Żyd lub sam judaizm, konkretne żydowskie osobliwości i zamiar antysemity, by je zniekształcić. Dzieje się tak, ponieważ antysemityzm zawsze istnieje w umyśle antysemity, ale potrzebuje swego obiektu - Żyda lub judaizmu, by się wyzwolić (s. 7 n.).

$\mathrm{Na}$ ile wszakże powyższe ustalenia pozwalają nam zrozumieć te źródła, które mówią w sposób wartościujący o Żydach, i w których wyraża się osobisty stosunek autora do tego narodu, jego religii i obyczajów? Weźmy na przykład Hekatajosa z Abdery. Przy założeniu, że Egipt przedhellenistyczny reprezentował ,antysemityzm in statu nascendi” a Egipt doby Ptolemeuszów oraz grecki Wschód „,antysemityzm w pełnym rozkwicie (anti-Semitism coming to full blossom)” (s. 209 n.), oraz mając na uwadze, że rdzeń tego „fenomenu” stanowi posądzenie o mizantropię/ksenofobię (s. 209 n.), można dojść do wniosku, że pierwszym antysemitą był nie kto inny, jak Hekatajos! Co więcej, trzymając się ustaleń Schäfera, gdy inkryminowany autor wszedł w konflikt z Żydami, w jego umyśle uruchomiły się antysemickie mechanizmy (bo był Grekiem). Stał się on zatem wrogiem Żydów, na równi z Apionem, Hamanem czy Heinrichem von Treitschke. W konsekwencji rodzi się podejrzenie, że dla 
Schäfera pozytywne wzmianki o wyznawcach Jahwe, które bezspornie przeważają w jego dziele $O$ Egipcie, mają niewielką wartość, albo że zdał się on całkowicie na wykreowany przez siebie szablon, który pozwala za pomocą pewnego motywu na ustalenie, kto jest, a kto nie jest antysemitą. Niewątpliwie takie „ułatwienia” prowadzą do sztucznych uproszczeń. Nie oznacza to wszakże, iż należy odrzucić w całości model proponowany przez niemieckiego uczonego. Pozwala on bowiem na uchwycenie istoty wrogości wobec Żydów, lub ostrożniej: stanowi jeden z przyczynków do zrozumienia tego niepokojącego zjawiska, jakim jest wrogość w stosunku do nich. Piszący te słowa opowiada się za ostrożniejszym stosowaniem jednolitych matryc do wielokształtnej sfery ludzkiej myśli, mającej przecież indywidualne rysy.

Pewnym mankamentem tej książki jest to, że nie traktuje ona prawie wcale o wydarzeniach, w których Żydzi nie byli wcale ofiarami. Schäfer uwzględnił w swej książce wypadki z Elefantyny, z Aleksandrii w 38 roku, prześladowania za Antiocha Epifanesa oraz wygnania z Rzymu. Nawet pobieżna znajomość dziejów narodu żydowskiego pozwala dostrzec, że wszędzie tam byli oni ofiarami Egipcjan, Greków i Rzymian. Czytelnik, skonfrontowany z taką sytuacją, jest w podobnym położeniu jak oglądający jedną stronę medalu. Autor nie wzmiankuje udziału Żydów w walkach dynastycznych Ptolemeuszy, zajęcia strony Rzymian, gdy ci najechali Egipt w 55 i w 45 r. p.n.e., rozruchów z 41 i 66 roku w Aleksandrii i wreszcie wielkiego powstania w diasporze z lat 115(6)117. Wszędzie tam Żydzi byli nie tylko ofiarami, ale odgrywali rolę aktywnych uczestników, niekiedy nawet inicjatorów tych starć. Omawiana książka nie poddaje się jednoznacznej ocenie. W swej pierwszej części prezentuje dosyć dokładną i wyważoną analizę poszczególnych źródeł, a pewne uogólnienia, np. dotyczące stosunku Rzymian do Żydów, wydają się dosyć ciekawe i nowatorskie. Jednak ogólna koncepcja dotycząca istoty antysemityzmu, choć oryginalna i nie pozbawiona wartości, powinna być stosowana nieco ostrożniej, niż to zdaje się czynić autor.

Wojciech Bejda - Lublin

\section{Stanisław KALINKOWSKI, Jerzy Andrzej WOJTCZAK-SZYSZKOWSKI, Iure et legibus. Język taciński dla studentów prawa, Warszawa 2000, Wyższa Szkoła Handlu i Prawa im. R. Lazarskiego, ss. 232.}

Wyrażam głęboką radość, że na rynku księgarskim ukazał się nowy podręcznik do języka łacińskiego dla studentów prawa. Studenci do tej pory mieli tylko jeden podręcznik Jana Rezlera, Język taciński dla prawników (wyd. 1, Warszawa 1970, PWN, ss. 284), który już jest nieco przestarzały i nie dostosowany do współczesnych wymogów nauczania. 